\title{
Study of Chemical Composition and Some Material Properties for a Hybrid Resin Based on Dammar
}

\author{
VLAD ALEXANDRU GEORGEANU ${ }^{1}$, MARIUS MARINEL STANESCU², \\ DUMITRU BOLCU ${ }^{2 *}$, ION CIUCA ${ }^{3}$, MIHAELA BOGDAN ${ }^{2}$, \\ SABO ANCA ALEXANDRA IORDACHE \\ ${ }^{1}$ University of Medicine and Pharmacy "Carol Davila" Bucharest, Faculty of Medicine, 37 Dionisie Lupu Str., 020021, \\ Bucharest, Romania \\ ${ }^{2}$ University of Craiova, Faculty of Mechanics, 165 Calea Bucuresti, 200620, Craiova, Romania \\ ${ }^{3}$ Politehnica University of Bucharest, Faculty of Engineering and Materials Science, 313 Splaiul Independentei, 060042 , \\ Bucharest, Romania \\ ${ }^{4}$ Politehnica University of Bucharest, Faculty of Industrial Engineering and Robotics, 313 Splaiul Independentei, 060042 , \\ Bucharest, Romania
}

\begin{abstract}
The chemical composition of a hybrid resin made of natural Dammar resin and epoxy resin (along with the related hardener), in proportion of volume of $60 \%$ and $40 \%$, respectively, was studied based on EDS (Energy Dispersive Spectroscopy) analysis. The presence of epoxy resin was necessary to generate a rapid polymerization process. The material details of the hybrid resin were investigated using SEM (Scanning Electron Microscopy). A high-resolution image of a hybrid resin sample was obtained. The weight loss of the hybrid resin at certain temperature values using thermo gravimetric analysis was measured. In addition, the surface roughness of the hybrid resin was characterized using two methods. By the first method, the classical one, the roughness was measured using two profile parameters and five analysis lines, namely the functional dependence between the roughness height and the gray level of the analyzed surface image. By the second method, the average roughness method, the surface texture of a hybrid resin specimen was measured and the roughness profile was obtained as the difference between the primary profile and the middle line of the filter determined with the Gaussian profile filter. Finally, several possible areas of use of this type of resin have been proposed based on the properties obtained.
\end{abstract}

Keywords: hybrid resin, chemical composition, thermal stability, roughness

\section{Introduction}

Natural resins are a mixture of volatile aromatic chemicals and are produced by plants or animals. Natural resins are not soluble in water, but are easily soluble in oil, alcohol and partially in gasoline. In combination with certain organic solvents (turpentine, rosin) these resins form solutions that can be used as coating varnishes [1-4]. A disadvantage for natural lakes is that they cannot form thick resins [1-2]. One solution to eliminate this drawback is to use hybrid resins obtained by combining several constituents, of which at least one is organic and at least one is synthetic [5].

One of the most used natural resins is Dammar. It is harvested from trees of the Dipterocarpaceae family in India and East Asia. The soil where these trees grow influences the appearance of macro and microelements in the chemical structure of Dammar resin, i.e. additional elements may appear such as: iron, silicon, zirconium, cadmium and so on.

Dammar films, in the form of varnish, are used to protect paintings [6]. The effect of long exposure to acetic acid of paintings coated with Dammar-based varnish, which generates an accelerated degradation of them, was investigated in the paper [7-8].

Using a multi analytical approach based on thermo gravimetric analysis coupled with infrared spectroscopy (TGA-FTIR), in the paper [9] was clarified the nature of the macromolecular components of Dammar resin.

*email:dbolcu@yahoo.com 

[11].

The structure and chemical composition of Dammar resin have been studied in detail in [10] and

Dammar in combination with silicone was used to obtain "ecological" types of binders. In the work [12] a study was carried out on the optimization of the quantities of Dammar and silicone in the composition of "ecological" binders, used to cover aluminum panels, so that they have good properties for impact, hardness, traction and adhesion. The influence of adding Dammar to improving the rigidity, modulus of elasticity and hardness of "ecological" binders was studied in [13].

Paper [14] aimed to expand knowledge about the bio microbiological deterioration of Dammar-based lakes in works of art subject to unsuitable protective conditions, especially long exposures to high levels of relative humidity, suggesting that some microorganisms favor processes. of natural damage to the films of Lake Dammar.

The effect of polymethylmethacrylate (PMMA) on the physical properties of Dammar for the application of coating paints was investigated in [15]. It has been found that Dammar when mixed with PMMA can be used for cold coating of rolled steel.

The interdependence between the surface roughness and its image is based, in principle, on the functional dependence between the roughness height and the gray level of the surface image, in the sense that the higher parts of the roughness correspond to the higher intensity pixels [16-17].

\section{Materials and methods}

\subsection{Manufacture of test specimens}

It should be noted that the temperature of the medium in which the casting was performed was 21$23^{\circ} \mathrm{C}$. All specimens were cut 10 days after pouring the plate.

A hybrid resin plate was poured, in which Dammar was used in a volume proportion of $60 \%$. The difference up to $100 \%$ consisted of Resoltech 1050 type epoxy resin together with the corresponding Resoltech 1055 type hardener. The synthetic component (epoxy resin and hardener) were required to generate rapid activation points of the polymerization process.

The volume ratio of the combination of the two synthetic components Resoltech 1050 / Resoltech 1055 was 7/3 (according to the manufacturer's instructions). The manufacturer in [18] gives the thermomechanical properties of Resoltech 1050 epoxy resins together with the Resoltech 1055 hardener.

A set of twenty specimens marked with Dammar 1.1-20 was cut from the cast plate. The dimensions of the specimens were length $250 \mathrm{~mm}$, width $25 \mathrm{~mm}$ and thickness $6.2 \mathrm{~mm}$. The density of the specimens was between $1.04-1.05 \mathrm{~g} / \mathrm{cm}^{3}$. Figure 1 shows a specimen from this set.

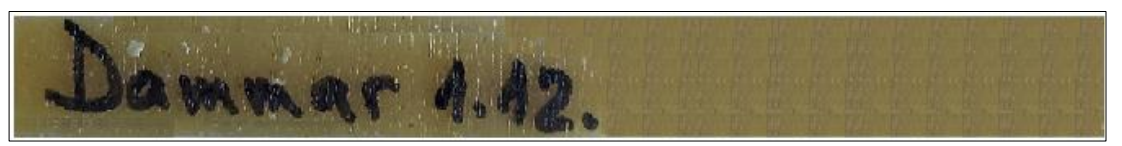

Figure 1. Hybrid resin specimen with a volume ratio of $60 \%$ Dammar

\subsection{Methods of analysis and apparatus used in the tests}

The chemical composition of a hybrid resin sample was determined based on EDS analysis. This analysis was performed using a PHENOM PURE PRO X scanning electron microscope [19], with integrated EDS system, with conventional cathode for microscopic study of the structures and surface of different materials, with the possibility of determining the chemical composition and phases in the structure. The possibility of magnification is between 80-130000 times. Among the types of materials for which are used are composite materials with polymer or metal matrix.

The roughness analysis for a hybrid resin sample was performed with the PHENOM PURE PRO X microscope because it is equipped with lighting through objective In addition, the Taylor Hobson Surtronic 3+ surface roughness tester [20] was used to obtain a numerical roughness assessment for a hybrid resin specimen, by what is known as the Ra method (roughness average method). 
SEM analysis was performed with an electron microscope - Hitachi model S3400N / type II [21], with the following characteristics:

- SE image resolution: minimum $3.0 \mathrm{~nm}$ at $30 \mathrm{kV}(\mathrm{x} 100,000, \mathrm{WD}=5 \mathrm{~mm}$, high vacuum mode $)$; minimum $10 \mathrm{~nm}$ at $3 \mathrm{kV}(\mathrm{x} 30,000, \mathrm{WD}=5 \mathrm{~mm}$, high vacuum mode);

- BSE image resolution: minimum $4.0 \mathrm{~nm}$ at $30 \mathrm{kV}(x 60,000, \mathrm{WD}=5 \mathrm{~mm}$, low vacuum mode);

- magnification: between x5 - x300,000;

- acceleration voltage: $0.3 \mathrm{kV}-30 \mathrm{kV}$;

- electron gun voltage: in steps with own field and with fixed field with continuously adjustable voltage;

- beam alignment: two-stage electromagnetic deflector;

- objective aperture: 4 holes with click-stop system with a diameter of 30, 50, 80 and 150 microns;

- image displacement: minimum \pm 50 microns at $\mathrm{WD}=10 \mathrm{~mm}$.

EDS and SEM analyzes were performed in accordance with the provisions of [22].

Based on the thermo gravimetric analysis (TGA), the thermal stability of a hybrid resin sample was determined. We used a Thermo gravimetric Q50 Analyzer connected to a desktop (which can heat a sample up to $1000^{\circ} \mathrm{C}$ ) and software for experimental analysis of Universal Analysis 2000 data, which offers weight loss at certain temperature values. TGA analysis was performed according to the provisions of [23].

The functional groups and chemical composition of the hybrid resin was determined based on FTIR (Fourier Transformed Infrared Spectroscopy) analysis.

FTIR analysis was performed using a portable IdentifyIR system (equipped with ChemAssist software) $[24,25]$ have been complied with. The sample size used was less than $5 \mu \mathrm{L}$ or $100 \mu \mathrm{m}$. In addition, the equipment was presented with the Aldrich / Smiths ATR spectral libraries. All the technical characteristics of this system can be found on the manufacturer's website [26].

\section{Results and discussions}

Figure 2 shows the diagram of the EDS analysis of the chemical composition for a hybrid resin sample, obtained at an intensity of $15 \mathrm{keV}$.

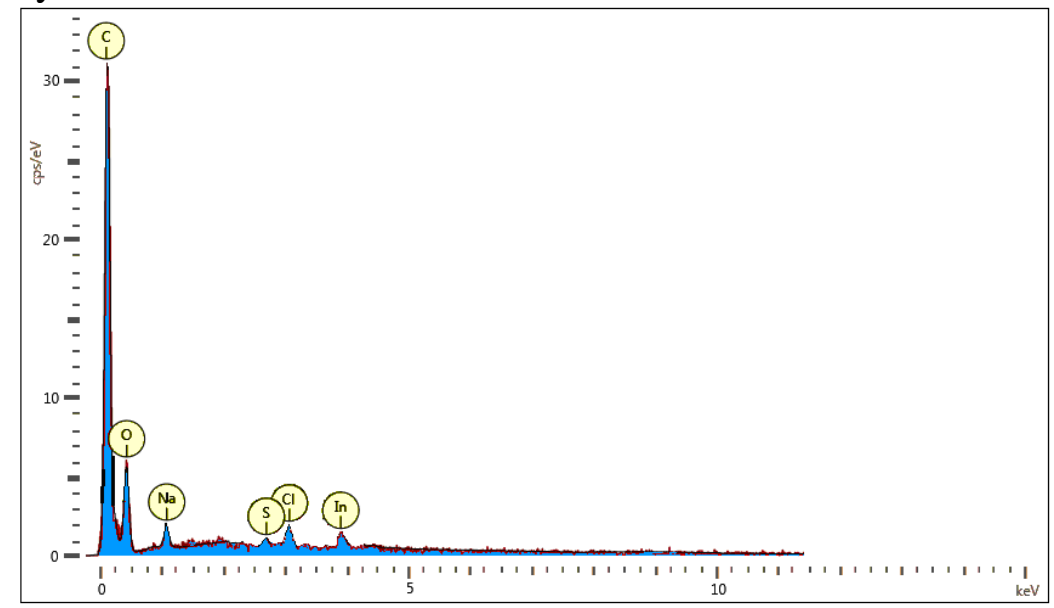

Figure 2. Diagram of the EDS analysis of the chemical composition for a hybrid resin sample, obtained at an intensity of $15 \mathrm{keV}$

Based on the EDS analysis, Table 1 shows the chemical composition of a hybrid resin sample. The weight concentration (Atomic Concentration) and the number of atoms in each element express this composition.

To determine the number of atoms in the weight concentration of an element the formula was used:

$$
\text { Atoms Numbers }=\frac{\text { Weight concentration } \cdot \text { Avogadro constant }}{\text { Atomic weight }}
$$


A total number of atoms equal to $\approx 45 \times 10^{23}$ (obtained as the sum of all numbers on the number of atoms column) was used.

Table 1. Chemical composition of a hybrid resin sample

\begin{tabular}{|c|c|c|c|c|c|c|}
\hline $\begin{array}{c}\text { Element } \\
\text { Number }\end{array}$ & $\begin{array}{c}\text { Element } \\
\text { Symbol }\end{array}$ & $\begin{array}{c}\text { Element } \\
\text { Name }\end{array}$ & $\begin{array}{c}\text { Atomic } \\
\text { Weight }\end{array}$ & $\begin{array}{c}\text { Atomic } \\
\text { Conc. } \\
\text { Wt. [\%] }\end{array}$ & $\begin{array}{c}\text { Weight } \\
\text { Conc. } \\
\text { At. [\%] }\end{array}$ & $\begin{array}{c}\text { Atoms } \\
\text { Numbers }\end{array}$ \\
\hline 6 & $\mathrm{C}$ & Carbon & 12 & 77.74 & 69.26 & $34.7569 \times 10^{23}$ \\
\hline 8 & $\mathrm{O}$ & Oxygen & 16 & 20.47 & 24.30 & $9.1459 \times 10^{23}$ \\
\hline 49 & $\mathrm{In}$ & Indium & 115 & 0.40 & 3.37 & $0.1764 \times 10^{23}$ \\
\hline 17 & $\mathrm{Cl}$ & Chlorine & 35.5 & 0.59 & 1.56 & $0.2646 \times 10^{23}$ \\
\hline 11 & $\mathrm{Na}$ & Sodium & 23 & 0.59 & 1.01 & $0.2644 \times 10^{23}$ \\
\hline 16 & $\mathrm{~S}$ & Sulphur & 32 & 0.21 & 0.50 & $0.0940 \times 10^{23}$ \\
\hline
\end{tabular}

The material details of the hybrid resin were investigated using SEM. Figure 3 shows a high-resolution image of a sample of this type of resin.

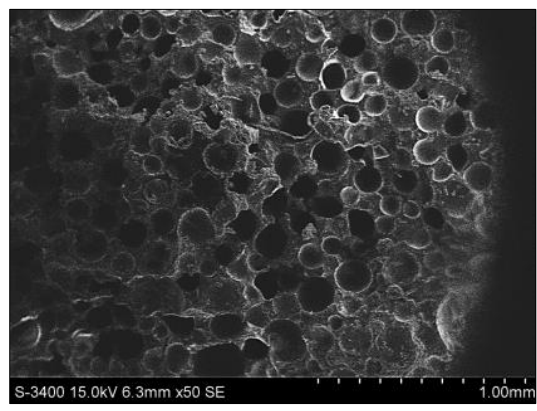

Figure 3. SEM analysis for a hybrid resin sample

For the thermo gravimetric analysis, a hybrid resin sample was heated to a chosen temperature of $800^{\circ} \mathrm{C}$ (because it was considered that no significant changes will occur above this value) and the weight change was determined.

After the experiment, the air cooled in $20 \mathrm{~min}$. The gas used in this experiment was nitrogen with a purity of 5.0. A sample with a mass of $0.63 \mathrm{mg}$ was taken from the samples made from hybrid resin. This sample was loaded into the platinum vessel at the appliance (the sample was crushed before loading).

The weight loss of the hybrid resin, obtained from the experimental data, compared to the temperature is shown in Figure 4 a, and the thermo gravimetric curve is shown in Figure $4 \mathrm{~b}$.

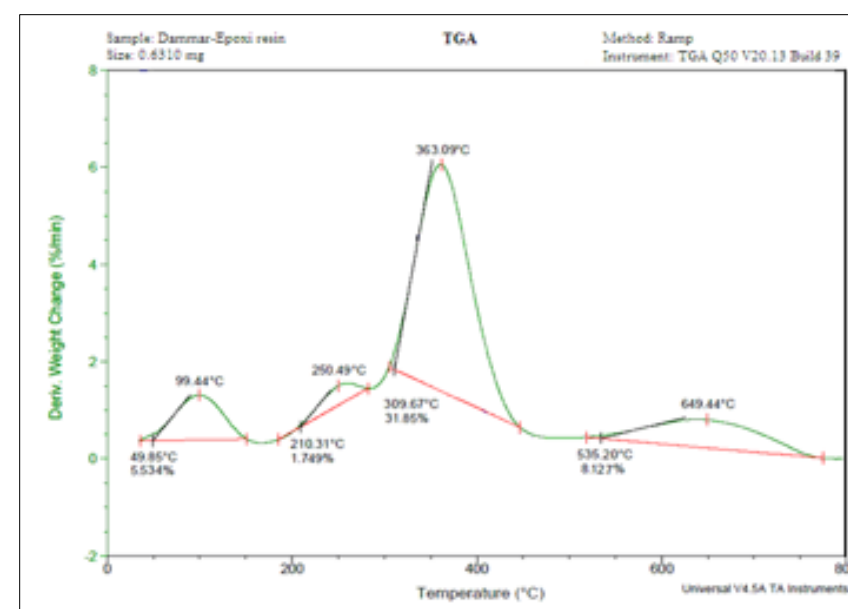

a)

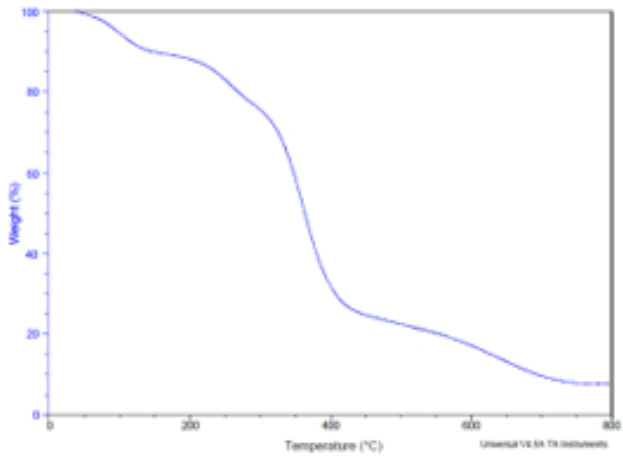

b)

Figure 4. a) Deriv. weight change of hybrid resin at various temperatures;

b) The weight loss (\%) of hybrid resin at various temperatures 
From the previous figure, five distinct stages of weight loss of the hybrid resin can be observed, as follows:

- weight loss of $0.5534 \% \cdot \mathrm{min} /{ }^{\circ} \mathrm{C}$ from $49.85^{\circ} \mathrm{C}$ to $150^{\circ} \mathrm{C}$, with a peak value up to $99.44{ }^{\circ} \mathrm{C}$; this case occurs mainly due to the evaporation of the parts of water that make up the resin;

- a weight loss of $0.1749 \% \cdot \mathrm{min} /{ }^{\circ} \mathrm{C}$ from $210.31^{\circ} \mathrm{C}$ to $300^{\circ} \mathrm{C}$, with a maximum value of $250.49^{\circ} \mathrm{C}$; residual values of epoxy resins and Dammar remain;

- a weight loss of $3,185 \% \cdot \min /{ }^{\circ} \mathrm{C}$ from $309.67^{\circ} \mathrm{C}$ to approximately $450^{\circ} \mathrm{C}$, with a maximum value at $363.090 \mathrm{C}$; residual values of epoxy resins and Dammar remain;

- a weight loss of $0.8127 \% \cdot \mathrm{min} /{ }^{\circ} \mathrm{C}$ from about $535.20^{\circ} \mathrm{C}$ to about $785^{\circ} \mathrm{C}$, with a peak value of $649.44^{\circ} \mathrm{C}$;

-no final changes are observed from 785 to $800^{\circ} \mathrm{C}$.

Figure 5a shows the roughness analysis for a hybrid resin sample. The roughness value was calculated on the profile, using five lines of analysis. Figure $5 \mathrm{~b}$ shows the roughness analysis of the same resin monster using the functional dependence between the roughness height and the gray level of the surface images.

The roughness analysis was performed in accordance with [27, 28].

To characterize the roughness, it is used two profile parameters $R_{z}$ and $R_{a}$. The parameter $R_{z}$ represents the average of all the maximum differences between the maximum and the minimum point at the profile within the evaluation length, and $R_{a}$ is the arithmetic mean of the absolute deviations of the roughness profile from the midline.

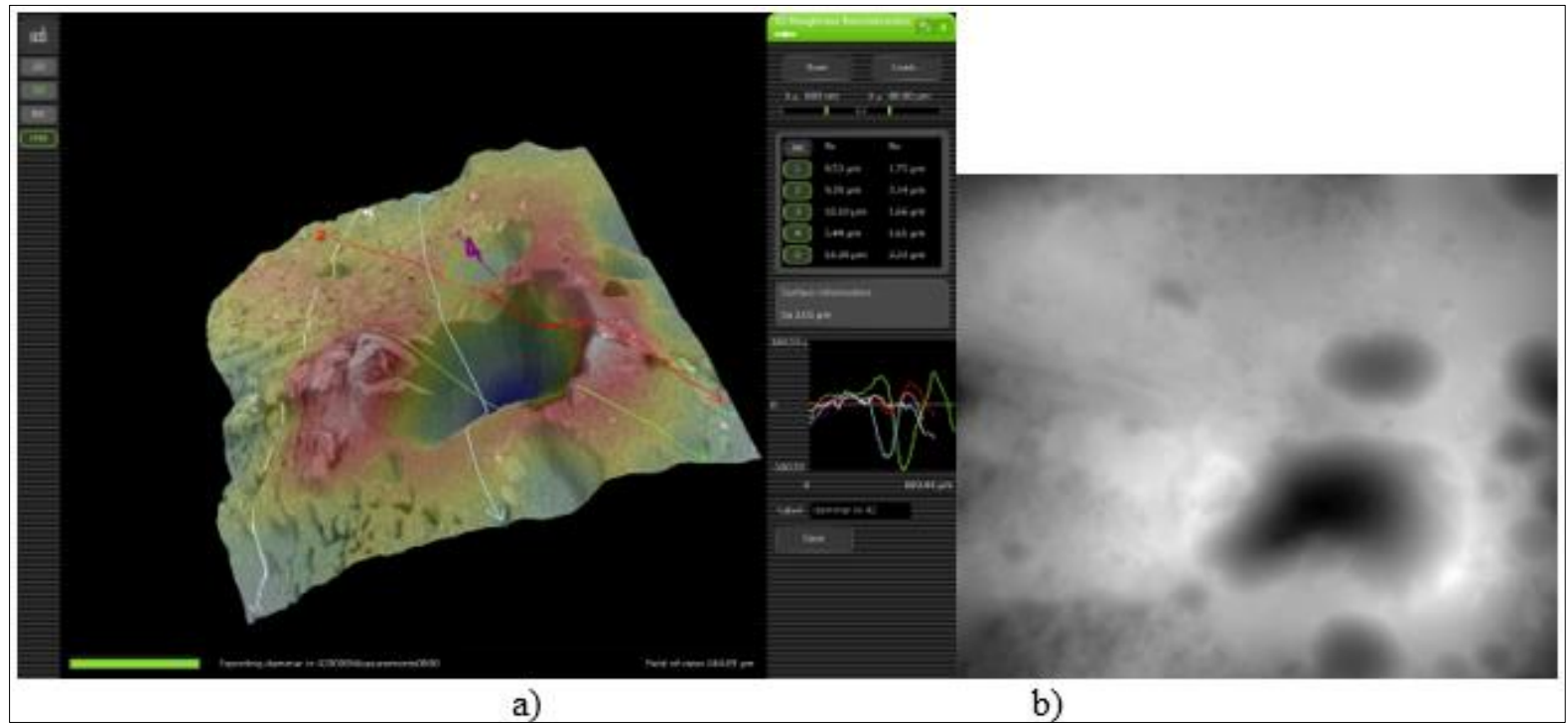

Figure 5. Roughness analysis for a hybrid resin sample: a) on the 5 lines of analysis; b) using the functional dependence between the height of the roughness and the gray level of the surface images

The values of the roughness profile parameters are presented in Table 2.

Table 2. Roughness profile parameters

\begin{tabular}{|c|c|c|}
\hline No. & $\mathrm{R}_{\mathrm{z}}$ & $\mathrm{R}_{\mathrm{a}}$ \\
\hline 1 & $9.53 \mu \mathrm{m}$ & $1.75 \mu \mathrm{m}$ \\
\hline 2 & $9.39 \mu \mathrm{m}$ & $2.14 \mu \mathrm{m}$ \\
\hline 3 & $10.10 \mu \mathrm{m}$ & $1.66 \mu \mathrm{m}$ \\
\hline 4 & $5.44 \mu \mathrm{m}$ & $1.61 \mu \mathrm{m}$ \\
\hline 5 & $13.28 \mu \mathrm{m}$ & $2.23 \mu \mathrm{m}$ \\
\hline
\end{tabular}

The surface texture of a hybrid resin specimen was measured using the medium roughness method. 
The roughness profile was obtained as the difference between the primary profile and the middle line of the filter determined with the Gaussian profile filter. Figure 6 shows the tester used by this method of measuring surface roughness.

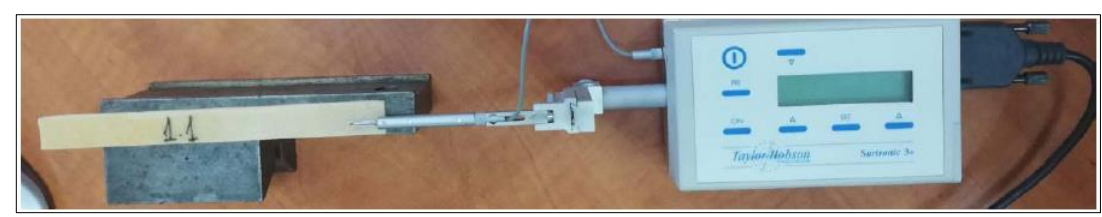

Figure 6. Taylor Hobson Surtronic 3+ surface roughness tester

Figure 7 shows the general roughness profile, and Figure 8 shows the roughness profile determined using the Gaussian filter. This type of filter was introduced in [29] (for profiles) and with its help the mean line can be determined in surface metrology. Its weighting function is given by the expression:

$$
h(t)=\frac{1}{\alpha \lambda_{c}} e^{-\pi\left(\frac{t}{\alpha \lambda_{c}}\right)^{2}},
$$

where: $\alpha=0.4697, t$ is the position relative to the origin of the weighting functions, and $\lambda_{\mathrm{c}}$ is the cut-off wavelength of the filter (in units of $t$ ).

If it used $x(t)$ for the position of the unfiltered primary profile, $m(t)$ for the Gaussian filtered mean line and $r(t)$ for the roughness profile, then:

$$
m(t)=x(t) * h(t)
$$

and

$$
r(t)=x(t)-m(t)
$$

where $*$ means product of convolution to functions $x(t)$ with $h(t)$, i.e.:

$$
x(t) * h(t)=(x * h)(t)=\int_{-\infty}^{+\infty} x(\tau) h(t-\tau) d \tau .
$$

The amount of data removed by the Gaussian filter is smaller than that of filters obtained by other methods and thus the roughness profile is more accurate.

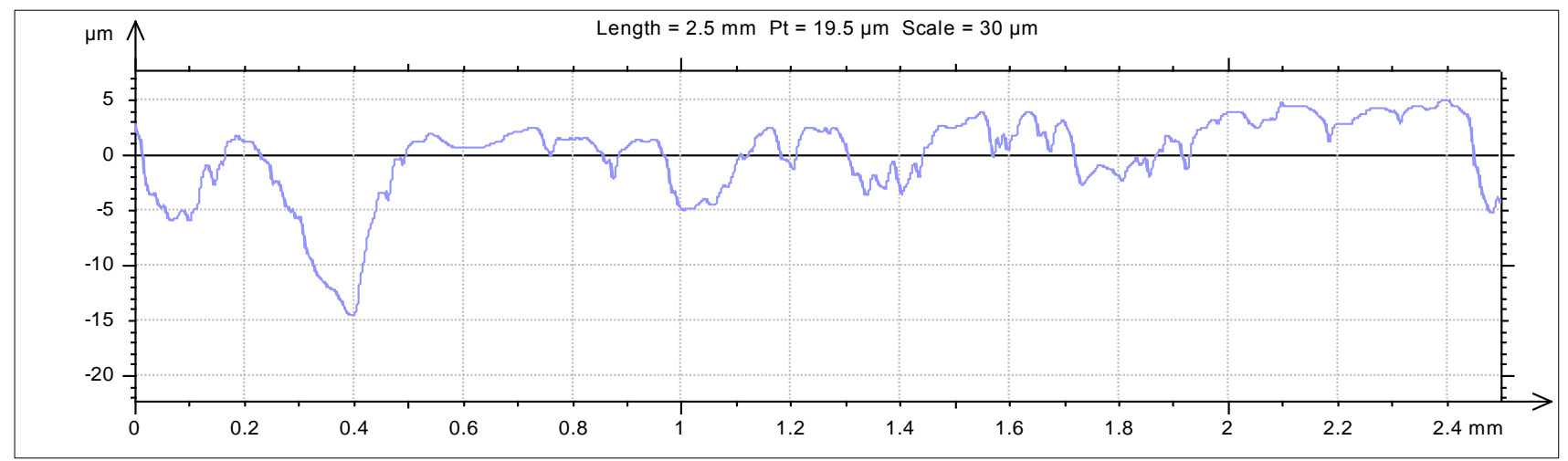

Figure 7. General roughness profile 


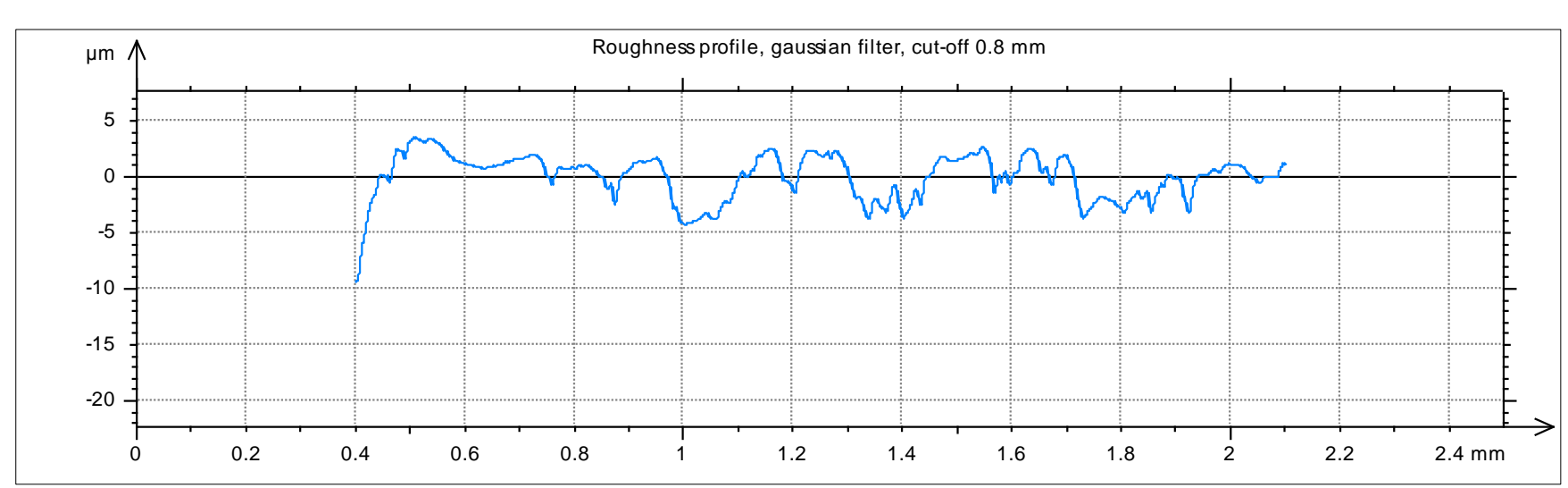

Figure 8. Roughness profile determined using a Gaussian filter

The data obtained are $R_{a}=1.76 \mu \mathrm{m}, \mathrm{R}_{\mathrm{t}}=13.10 \mu \mathrm{m}$ and $\mathrm{R}_{\mathrm{z}}=9.83 \mu \mathrm{m}$.

Figure 9 shows the FTIR analysis diagram for a hybrid resin sample.

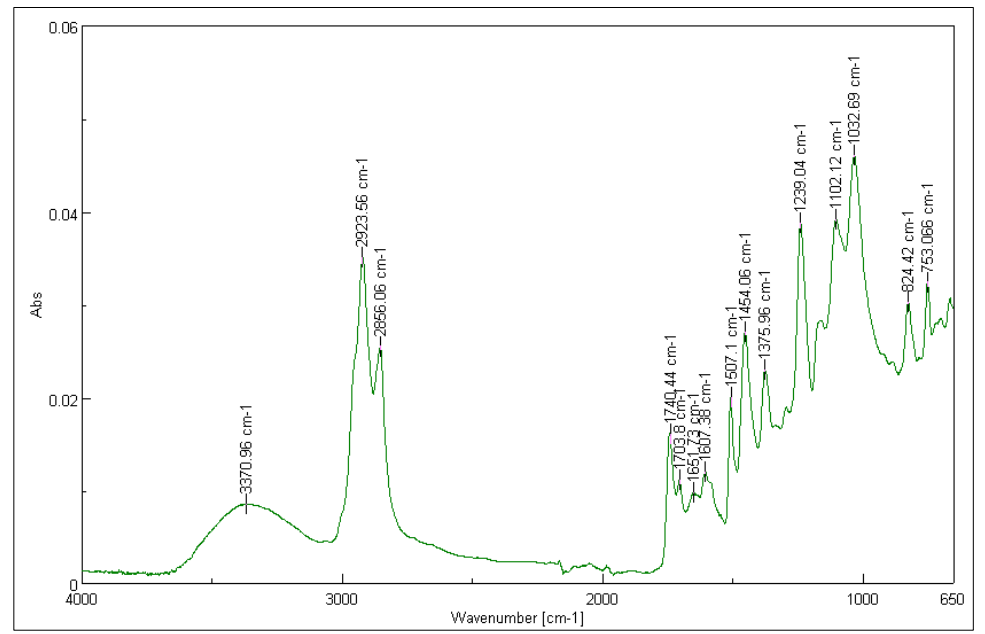

Figure 9. FTIR analysis of a hybrid resin sample

Based on the FTIR analysis of the spectrum of a hybrid resin sample, the following structural identification was obtained:

- $3371 \mathrm{~cm}^{-1}$ indicates the presence of N-H groups in the structure of an aliphatic primary amine;

- 3050-2800 $\mathrm{cm}^{-1}$ there is the stretching of the aromatic and aliphatic C-H bonds;

$-1608 \mathrm{~cm}^{-1}$ the extension of the $\mathrm{C}=\mathrm{C}$ bonds of the aromatic rings occurs;

$-1507 \mathrm{~cm}^{-1}$ there is an extension of the aromatic $\mathrm{C}-\mathrm{C}$ bonds;

- $1454 \mathrm{~cm}^{-1}$ indicates the presence of methylene $(\mathrm{CH} 2)$ groups;

- the additional presence of the $1376 \mathrm{~cm}^{-1}$ peak is caused by a methyl (CH3) group;

- $1033 \mathrm{~cm}^{-1}$ the $\mathrm{C}-\mathrm{O}-\mathrm{C}$ stretch of the ethers occurs;

- $824 \mathrm{~cm}^{-1}$ the $\mathrm{C}-\mathrm{O}-\mathrm{C}$ extension of the oxirane groups occurs;

- $763 \mathrm{~cm}^{-1}$ the oscillating movement (rocking) of $\mathrm{CH} 2$ occurs.

\section{Conclusions}

From the diagram of the EDS analysis of a hybrid resin sample, it can be seen that oxygen has a significant share in its composition. This fact, is also certified by the SEM analysis, which shows the existence of a large number of air gaps in the structure of the hybrid resin. The explanation may be that the curing time and implicitly the duration of the polymerization process is much longer for the hybrid resin than for the epoxy resin and thus some of the air bubbles formed during the curing process remain trapped inside the resin. 
The presence of air bubbles in the structure of the hybrid resin increases the roughness of the analyzed surface. This can be seen in Figure 5b, by the extended presence of shades of gray.

The values of the roughness profile parameters, presented in Table 2 and functional dependence between the roughness height and the gray level of the surface images for the hybrid resin sample (Figure $5 b$ ), indicate that we have an average roughness.

From the two experimental ways of determining the roughness parameters, it is observed that there are insignificant differences between their values.

IR spectroscopy is an extremely effective method for determining the presence or absence of a wide variety of functional groups in a molecule. IR spectra can be used to identify the molecule by recording the spectrum for an unknown and comparing this information with the library or a database of spectra of known compounds.

Two functional groups can be distinguished from the FTIR analysis diagram of a hybrid resin sample:

1. cumulative Ketene type double bonds $(\mathrm{CH} 2=\mathrm{C}=\mathrm{O})$, which are substances with a combined carbonyl and carbon-carbon double bonds;

2. Nitrogen double bond, known as the Nitrite ion $\left(\mathrm{NO}_{2}\right)$ and it contains nitrogen in a relatively unstable oxidation state.

From the analysis of the thermo gravimetric curve (Figure 4b) it can be seen that the highest percentage weight loss of the analyzed hybrid resin sample occurs in the temperature range between 300 and $450^{\circ} \mathrm{C}$.

When we obtained this hybrid resin, we thought about the possibility of using a matrix in the manufacture of "environmentally friendly" composite materials, by reinforcing them with various types of natural reinforcers.

These composite materials can be used in:

-the field of civil and industrial constructions, making paneling and parquet boards;

-the medical field, for the manufacture of elements to replace gypsum dressings using the immobilization of fractures of the tibia, arm, forearm, etc.

In a subsequent study we will investigate, how the roughness and composition of material will influence the wetting properties by measuring the contact angle (ex. water).

\section{References}

1.KAMARHATI, S., YOGI, H., LU, R., MIYAKOSHI, T., Development of bio-based hybrid resin, from natural lacquer, Prig. Org. Coat., 77, 2014, 24-29,

http://dx.doi.org/10.1016/j.porgcoat.2013.07.013

2.ISHIMURA, T., LU, R., YAMASAKI, K., MIYAKOSHI, T., Development of an eco-friendly hybrid lacquer based on kurome lacquer sap, Prog. Org. Coat., 69(1), 2010, 12-15, https://doi.org/10.1016/j.porgcoat.2010.04.019

3.DRISKO, G.L., SANCHEZ, C., Hybridization in materials science-Evolution, current state, and future aspirations, Eur. J. Inorg. Chem., 32, 2012, 5097-5105, https://doi.org/10.1002/ejic.201201216

4.SCALARONE, D., DOUSMAN, M.R., BOON, J.U., CHANTER, O., MALDI-TOF mass spectrometry on cellulosic surfaces of fresh and photo-aged di- and triterpenoid varnish resins, J. Mass Spectrom., 40(12), 2005, 1527-1535, https://doi.org/10.1002/jms.893

5.STĂNESCU, M.M., BOLCU, D., A study of some mechanical properties of a category of composites with a hybrid matrix and natural reinforcements, Polymers, 11(3), 2019, 478,

https://doi.org/10.3390/polym11030478

6.ROMERO-NOGUERAM, J., MARTÍN-SÁNCHEZ, I., LÓPEZ-MIRAS, M.M., RAMOS-LÓPEZ, J.M., BOLÍVAR-GALIANO, F., Biodeterioration patterns found in Dammar resin used as art material, Electron. J. Biotechnol., 13(3), 2010, 1-8. https://doi.org/10.2225/vol13-issue3-fulltext-7

7.BONADUCE, I., et. al., The role of organic and inorganic indoor pollutants in museum environments in the degradation of dammar varnish, Analyst, 138, 2013, 487-500,

https://dx.doi.org/doi:10.1039/C2AN36259G 
8.LA NASA, J., et. al., Effects of acetic acid vapour on the ageing of alkyd paint layers: multi analytical approach for the evaluation of the degradation processes, Polyp. Degrade. Stab., 105, 2014, 257-264, https://doi.org/10.1016/j.polymdegradstab.2014.04.010

9.BONADUCE, I., Di GIROLAMO, F., CORSI, I., DEGANO, I., TINÈ, M.R., COLOMBINI, M.P., Terpenoid oligomers of Dammar resin, J. Nat. Prod., 79(4), 2016, 845-856,

https://doi.org/10.1021/acs.jnatprod.5b00916

10.HIDAYAT, A.T., FARABI, K., HARNETI, D., MAHARANI, R., MAYANTI, T., SETIAWAN, A.S., SUPRATMAN, U., SHIONO, Y., Cytotoxicity and structure activity relationship of Dammaranetype triterpenoids from the bark of aglaia elliptica against P-388 murine leukemia cells, Nat. Prod. Sci., 23(4), 2017, 291-298, https://doi.org/10.20307/nps.2017.23.4.291

11.UKIYA, M., KIKUCHI, T., TOKUNDA, H., TABATA, K., KIMURA, Y., ARAI, T., EZAKI, Y., OSETO, O., SUZUKI, T., AKIHISA, T., Antitumor-promoting effects and cytotoxic activities of Dammar resin triterpenoids and their derivatives, Chem. Biodivers., 7(8), 2010, 1871-1884, https://doi.org/10.1002/cbdv.201000107

12.ZAKARIA, R.; AHMAD, A.H. Adhesion and hardness evaluation of modified silicone-Dammar as natural coating materials, Am. J. Appl. Sci., 9(6), 2012, pp. 890-893,

https://thescipub.com/abstract/10.3844/ajassp.2012.890.893

13.ZAKARIA, R., AHMAD, A.H., The performance of modified silicone-Dammar resin in nanoindentation test, Int. J. Adv. Sci. Technol., 42, 2012, 33-44,

http://article.nadiapub.com/IJAST/vol42/4.pdf

14.PETHE, A.M., JOSHI, S.B., Physicomedical, Mechanical and film forming studies of novel biomaterial, IJPSR, 4(7), 2013, 2761-2769, https://doi.org/10.13040/IJPSR.0975-8232.4(7).2761-69

15.MOHANTY, A.K., MISRA, M., HINRICHSEN, G., Biofibers, biodegradable polymers and biocomposites: an overview, Macromol. Mater. Eng., 276-277, 2000, 1-24,

https://doi.org/10.1002/(SICI)1439-2054(20000301)276:1<1::AID-MAME>3.0.CO;2-W

16.JOSSO, B., BURTON, D.R., LALOR, M.J., Wavelet strategy for surface roughness analysis and characterisation, Comput. Methods Appl. Mech. Eng., 191(8-10), 2001, 829-842,

https://doi.org/10.1016/S0045-7825(01)00292-4

17.YANAGI, K., HARA, S., ENDOH, T., Summit identification of anisotropic surface texture and directionality assessment based on asperity tip geometry, Int. J. Mach. Tools Manuf., 41(13-14), 2001, 1863-1671, https://doi.org/10.1016/S0890-6955(01)00050-5

18.***Resoltech 1050, Hardeners 1053 to 1059. Structural Lamination Epoxy System. Available online: www.scabro.com/images/.../1/.../Resoltech\%201050/DS-1050.pdf (accessed on 9 January 2020).

19.***Phenom Pure Pro X Microscope, The high-performance desktop SEM. Available online: https://www.atascientific.com.au/wp-content/uploads/2017/01/ThermoScientific-SpecSheet_Phenom-

ProX_LR.pdf (accessed on 9 January 2020).

20.***Taylor Hobson Surtronic 3+, Operating instructions. Available online: https://www.taylorhobson.com/-/media/ametektaylorhobson/files/learning\%20zone/user\%20guides/surtronic\%203-

plus\%20handbook.pdf?la=en (accessed on 9 December 2019).

21.***Hitachi Model S-3400N (Type II), PC-Based Variable Pressure Scanning Electron Microscope. Available online:

www.ntnu.edu/documents/140082/1269041159/S-3400NSpecifications.pdf/6b94c26fa9d4-4f36-82b37e9eb3603922 (accessed on 9 January 2020).

22.***ASTM E1508, Standard Guide for Quantitative Analysis by Energy-Dispersive Spectroscopy, https://www.astm.org/Standards/E1508.htm (accessed on 9 December 2019).

23.***ASTM E1131, Standard Test Method for Compositional Analysis by Thermogravimetry, https://www.astm.org/Standards/E1131.htm (accessed on 9 December 2019).

24.***ASTM E168, Standard Practices for General Techniques of Infrared Quantitative Analysis. Available online: https://www.astm.org/Standards/E168.htm (accessed on 9 December 2019). 
25.***ASTM E1252, Standard Practice for General Techniques for Obtaining Infrared Spectra for Qualitative Analysis. Available online: https://www.astm.org/Standards/E1252.htm (accessed on 9 December 2019).

26.***IdentifyIR (FT-IR analysis system). Technical Information. Available online:

http://www.betatekinc.com/pdf/smiths_detection_identifyir.pdf (accessed on 18 December 2019).

27.***ASTM D4417, Standard Test Methods for Field Measurement of Surface Profile of Blast Cleaned Steel, https://www.astm.org/Standards/D4417.htm (accessed on 9 December 2019).

28.***ASTM F2603, Standard Guide for Interpreting Images of Polymeric Tissue Scaffolds. Available online: https://www.astm.org/Standards/F2603.htm (accessed on 9 December 2019)

29.***ASME B46, Introduction to Surface Texture (Surface Roughness, Waviness, and Lay). Available online:https://www.asme.org/getmedia/71644d10-54c2-4c5d-9ab8-33ba0ba03650/28833.pdf (accessed on 9 December 2019).

Manuscript received: 2.11 .2020 